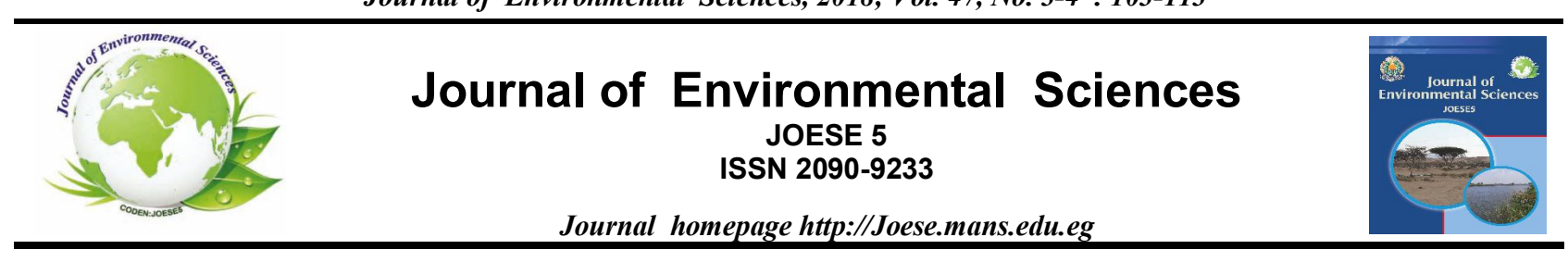

Original Article

\title{
The Potential Use of Pottery Jugs as Drinking Water Filters
}

\author{
Amany F. Hasballah \\ Environmental Sciences Department, Faculty of Sciences, Damietta University, Damietta, Egypt.
}

\begin{tabular}{|c|c|}
\hline Article Info & Abstract \\
\hline & The use of porous pottery jugs (fired clay) to the purification of drinking water and reduction \\
\hline Article history : & of heavy metals and other contaminants is the aim of this study. A total of twenty-eight samples \\
\hline Received 2/5/2018 & of drinking tap water tested for $\mathrm{pH}$, Turbidity, TDS, Electrical Conductivity, Salinity, $\mathrm{TH}, \mathrm{Ca}^{++}$ \\
\hline Received in revised & hardness, $\mathrm{Mg}^{++}$hardness and Total Coliform bacteria, in addition to some heavy metals $(\mathrm{Pb}, \mathrm{Zn}$, \\
\hline form 27/5/2018 & $\mathrm{Mn}, \mathrm{Fe}, \mathrm{Cd}$ and $\mathrm{Cu}$ ) in water before and after filtration also inside the jugs through 24 hour. The \\
\hline Accepted 2/7/2018 & paper discusses the ability for this technique to reduce such these pollutants that may be \\
\hline Keywords: & ts composition of silt and the high quality of clay. Pottery jugs (B) able to reduce the \\
\hline Pottery & ions of turbidity, $\mathrm{TH}, \mathrm{Ca}$ and $\mathrm{Mg}$ hardness. Also, improved its efficiency in \\
\hline Ceramic filter & significant difference between pottery jugs with physicochemical parameters and filtration \\
\hline Filtration & efficiencies. The concentrations of examined physicochemical parameters and heavy metals in \\
\hline Drinking water & drinking tap water and inside the pottery jugs and in the filtrate were within the safe limits of \\
\hline & EMH (2007), WHO (2011) and Egyptian Standards (EEAA, 1994) regulations, except the \\
\hline Heavy metals & concentration of $\mathrm{Fe}$ inside and in the filtrate, was above safe limit. \\
\hline
\end{tabular}

\section{Introduction}

The most deadly diseases being contacted from water are always from microbial particles or the presence of heavy metals that may be present in water through leaching or other processes. Most of the water resources in the countryside are contaminated with dissolved minerals and pathogenic organisms which can be highly infectious and disease-causing (Ajayi and Lamidi, 2015). Low scale water treatment techniques, boiling, chlorination, solar water disinfection, natural coagulation and bio-sand filtration are used to remove water related disease-causing microorganisms. Bio-sand filter can remove protozoa up to $100 \%$. Some of these techniques reduce the quality of water, and the side-products have an adverse effect on consumer health (Zereffa and Bekalo, 2017). Although municipal water in developed countries already falls into the World Health Organization (WHO) safe drinking water standards, water filters are still commonly used to improve taste or to eliminate any undesired matters. Various types of filters have been designed to be more suitable in the third world countries, but the cost is still not satisfactory, and many products are imported which further add to the cost. Their performance levels were determined by the removal efficiencies in terms of turbidity and microbiological

\footnotetext{
* Correspondence address:

Tel.: 020572403866

E-mail address:dr_env_env@yahoo.com
}

parameters. Ceramic water filtration as defined by Brown et al. (2007) is the process that makes use of a porous ceramic (fired clay) medium to filter microbes or other contaminants from water. The pore size of the ceramic medium is sometimes small enough to trap anything bigger than a water molecule. A porous media of fired clay retains microbes by size exclusion and high tortuous properties (it traps microbes in the sharp bends) (Sobsey et al., 2008; Hunter, 2009 and van der Laan et al., 2014). From the ancient times to the present, water filters have evolved out of necessity, first to remove materials that affect appearance, then to improve bad tastes and further to remove contaminants that can cause disease and illness, (Logsdon, 1990; LeChevallier and Au, 2000 and Ajayi and Lamidi, 2015). Baker (1948) he found that porous ceramic filters made of clay carved porous stone and other media used to filter water are rated to remove at least $99.9999 \%$ of bacteria, $99.99 \%$ of viruses, and $99.9 \%$ of Giardia cysts. Jaffar et al. (1990) used ceramic filters containing fired clay, limestone, lime and calcium sulfate have been produced for water filtration in Pakistan, and they found that the filters reduced turbidity by $90 \%$ and bacteria by $60 \%$. Also, Ajayi and Lamidi (2015) improve that a ceramic water filter composition can be effective for the removal of heavy metals and correction of physiochemical parameters in-home use water.

Most of Damietta governorate lands with agricultural activities. Where using the pesticides and fertilizers increase the pollution in water and plants. Thus the human health in 


\section{Journal of Environmental Sciences, 2018; Vol. 47, No. 3-4 : 103-113}

dangerous in Damietta Governorate especially after the construction of the industrial area, Damietta harbor, reclamation projects and agricultural development. The drinking water resources in the Damietta governorate comprise both Damietta Nile branch surface and ground waters. Water pollution is the main environmental problem in Damietta Governorate and the whole Arab Republic of Egypt. Pollution sources of Damietta Nile Branches water come from agricultural drains, domestic sewage, industrial effluents and fish farms (Al-Asmar, 2006). The use of wastewater in irrigation and sewage sludge has further increased the quantity of heavy metals in agricultural soils. The agricultural run-off together with soil erosion is considered as the potential source of water pollution. Metals get into the body through air, food, water, or dermal exposure. Metals have to cross the plasma membrane to enter the cell to exert toxicity. If a metal is in a lipophilic form, such as methylmercury and arsenic compounds, it readily penetrates the membrane. When bound to a protein, such as cadmium metal, the metal is actively taken into the cell by endocytosis. Human exposure to metals occurred since pre-historic time in areas where the heavy metal content of water and food were naturally high (Hasballah and Beheary, 2016). Believe of citizens in Egyptian villages that pottery jugs, which were manufacturing by mixing of clay-rich soil with water, sand, and remained pottery jugs and pressing into the cylinder and firing them at $900{ }^{\circ} \mathrm{C}$ for eight hours can act as a filter for tap drinking water. Using of the filtrate in cooking and other purposes making us focus the study on the potential use of such these pottery jugs in the purification of drinking water and reduction of heavy metals, and this is the aim of this study.

\section{Materials and Methods}

\subsection{Sampling}

Four samples of drinking tap water were collected from four main districts of Damietta governorate in Egypt country (EL-Zarka, Faraskor, Kafr- Saad and Damietta City) Figure 1. Twelve pottery jugs were purchased from three different Governorates, (Damietta, El-Gharbia, and El-Mnya), four jugs of each and divided to three groups according to the governorate (A, B, and C); respectively, Figure 2. All jugs washed and filled with drinking tap water for one day then remove the water and filled again and prepared for analysis. Drinking tap water was collected from houses into $1000 \mathrm{ml}$ acid-washed polyethylene (PE) bottles, and was transported to the laboratory where they were stored at $-4^{\circ} \mathrm{C}$ until analysis at the Faculty Laboratory, Accurate Analysis Unit, Damietta University. The pottery jugs filled with drinking tap water samples for 24 hours, physicochemical parameters of water samples were analyzed before putting the water in jugs and inside the pottery jug bodies, also the filtrate (the out of the pottery jug bodies) after 24 hours.

\subsection{Physico-Chemical Analysis of Drinking Water Samples}

Physical and chemical parameters of twenty-eight water samples (before, inside and filtrate) for each type of pottery jug bodies (A, B and C) were analyzed include: $\mathrm{pH}$, Turbidity, Total dissolved solids (TDS), Electrical conductivity (EC), Salinity, Total Hardness (TH), $\mathrm{Ca}^{++}$hardness and $\mathrm{Mg}^{++}$ hardness have been determined according to Standard Methods for Examination of Water and Wastewater (American Public Health Association), (APHA, 1992). Pottery jugs bodies' texture or composition was determined by Hydrometer Method as described by Piper (1947).

\subsection{Total Coliform MPN Analysis of Drinking Water Samples}

Multiple tube fermentation technique was performed according to APHA (1999). Presumptive phase MacConkey broth medium, which is commercially produced as a powder (OXOID, CM0505 (CM5a)) was used. $40 \mathrm{~g}$ of the medium was diluted in one liter of distilled water. Fermentation tubes were arranged in three rows of five tubes, and then Durham tube was added to each fermentation tube. The $\mathrm{pH}$ was adjusted at $7.4 \pm 0.2$. $10 \mathrm{ml}$ of the medium was distributed in each fermentation tube. Sterilization was done by autoclaving at $121^{\circ} \mathrm{C}$ for 15 minutes. Every five tubes were used for one dilution of sample $(10,1,0.1 \mathrm{ml}$ of the sample). Inoculated tubes were incubated at $37^{\circ} \mathrm{C}$ for $24 \mathrm{hr}$. After $24 \mathrm{hr}$, tubes were examined for acid and gas production. If no gas or acidic growth has formed tubes were re-incubated at the end of $48 \mathrm{hr}$. Then MPN was calculated.

\subsection{Heavy Metals Analysis of Drinking Water Samples}

Heavy metals concentration in drinking water was determined according to a method of AOAC (2000). A volume of $100 \mathrm{ml}$ of sample was measured into a beaker, and $5 \mathrm{ml}$ concentrated $\mathrm{HNO}_{3}$ was added. The mixture was boiled slowly on a hot plate or a steam bath until the volume has evaporated down to about $20 \mathrm{ml}$. A further five $\mathrm{mL}$ of concentrated $\mathrm{HNO}_{3}$ was added and the beaker covered with a watch glass and heated. Heating and adding concentrated $\mathrm{HNO}_{3}$ were continued until the solution has appeared light colored and clear. A 1-2 ml aliquot of concentrated $\mathrm{HNO}_{3}$ was added, and the mixture heated slightly to dissolve any remaining residues. The beaker walls and the watch glass were washed down with water which then is transferred to a $50 \mathrm{~mL}$ volumetric flask, cooled and the volume made up to the mark with water. The Inductively Coupled Plasma-Mass Spectrometry (ICP-OES 7000) was used for heavy metal analysis with an ultrasonic nebulizer (USN), this Nebulizer decrease the instrumental detection limits by $10 \%$, this ICP instrument is Perkin Elmer Optima 3000, USA.

\subsection{Calculation of Water Quality Index}

WQI is a mathematical way of summarizing multiple properties into a single value. WQI is useful for comparing differences in water quality across a region, or for monitoring changes in water quality over time. In the present study, WQI was calculated using the equation developed by Tiwari and Manzoor (1988). The quality rating (qi) for the water quality parameter can be obtained by the following relation:

$$
\mathrm{qi}=100 \mathrm{Vi} / \mathrm{Si} \text {...........(1) }
$$

Where Vi is the observed value of the parameter at a given sampling site, and $\mathrm{Si}$ is the stream water quality standard. 


\section{Journal of Environmental Sciences, 2018; Vol. 47, No. 3-4 : 103-113}

Equation (1) ensures that qi $=100$ if the observed value is just equal to its standard value. Thus, the larger value of qi revealed polluted water. To calculate WQI, the quality rating qi corresponding to the parameter can be determined using equation (2). The overall WQI was:

$$
\text { WQI }=\Sigma q i \ldots \ldots . . . .(2) \quad \text { Where } \mathrm{i}=1
$$

The average water quality index (AWQI) for $\mathrm{n}$ parameters was calculated using the following the equation (3):

$$
\mathrm{AWQI}=\Sigma \mathrm{qi} / \mathrm{n} \text {... }
$$

\subsection{Metal Pollution Index (MI)}

The pollution index (PI) was used in this study to evaluate the degree of heavy metal contamination in water samples (Emoyan et al., 2005 and Odukoya and Abimbola, 2010). The tolerable level is the element concentration in the water considered safe for human consumption (Lee et al., 1998). Pollution index (PI) is based on individual metal calculations and categorized into five classes according to the following equation (Caerio et al., 2005).

$$
P I=\sum_{i=1}^{n}\left(\frac{C_{i}}{S_{i}}\right) / N m
$$

Where $\mathrm{Ci}=$ Heavy metal concentration in water; $\mathrm{Si}=$ permissible Level and $\mathrm{Nm}=$ Number of Heavy metals. Water sample with Pollution Index $(\mathrm{PI})<1$ is regarded as being no effect; $(\mathrm{PI})=1-2$ (Slightly affected); (PI) = 2-3 (Moderately affected); (PI) = 3-5 (Strongly affected); (PI) = 4-5 (Seriously affected).

\section{Results and Discussion \\ 3.1. Physico-Chemical Analysis of Drinking Water Samples}

$\mathrm{pH}$ is an important indicator of water quality and the extent of pollution (Badr et al. 2013). Through results in Table 1, the mean concentration of $\mathrm{pH}$ in water in pottery jugs (A, B and C) through all sites increased inside and increased in the filtrate, to become slightly alkaline this change may be due to different dissolved gases and solids (Patil et al. 2012). $\mathrm{pH}$ was positively correlated with electrical conductance and total alkalinity (Guptaa, 2009). The mean concentration of TDS increased from $(226.75 \pm 14.08,192.25 \pm 4.99$ and $217.10 \pm 24.15 \mathrm{mg} / \mathrm{l})$ to $(256.50 \pm 11.01,201.75 \pm 5.50$ and $228.0 \pm 22.33 \mathrm{mg} / \mathrm{l}$ ) inside and increase in the filtrate to $(375.50 \pm 48.48,246 \pm 9.42$ and $571 \pm 83.57 \mathrm{mg} / \mathrm{l})$, respectively. Also, the mean concentration of EC increase from $(502 \pm 147.23, \quad 336.25 \pm 74.97$ and $443.25 \pm 60.95 \mu \mathrm{s} / \mathrm{cm})$ to (508.50 $\pm 19.07,406.75 \pm 13.5$ and $491.0 \pm 54.66 \mu \mathrm{s} / \mathrm{cm})$ inside and increase in the filtrate to $(776.0 \pm 115.14,505.25 \pm 21.08$ and $1022 \pm 142 \mu \mathrm{s} / \mathrm{cm}$ ), respectively. TDS increased inside the jugs and in the filtrate that may be attributed to leaching the component of the pottery jugs that may be discharged into the water (Sagara, 2000), and that may be attributed to high porosity of the filter elements that resulted from the higher percentage of burnout material in the composition (Zereffa and Bekalo, 2017). And that is in agreement with the results in Table 2, which show the increasing of the sand fraction percentage which reached to $(96,90$ and $90 \%)$ in pottery jugs (A, B and C), respectively. The mean concentration of salinity in water in pottery jugs (A, B and C) through all sites slightly increased from $(0.20 \pm 0,0.20 \pm 0$ and $0.20 \pm 0 \%)$ to $(0.23 \pm 0.04$, $0.20 \pm 0$ and $0.23 \pm 0.04 \%)$ inside and increase in the filtrate to $(0.35 \pm 0.05,0.23 \pm 0.05$ and $0.60 \pm 0.1 \%)$, respectively. The mean concentration of turbidity in water in pottery jugs (A and B) decreased from $(2.35 \pm 1.35$ and $2.63 \pm 0.56 \mathrm{NTU})$ to $(1.45 \pm 0.48$ and $1.79 \pm 0.67 \mathrm{NTU})$ inside and decreased in the filtrate to $(1.20 \pm 0.24$ and $1.60 \pm 0.29 \mathrm{NTU})$, respectively. On the other hand, the mean concentration of turbidity in water in pottery jugs (C) increased from $1.73 \pm 0.22 \mathrm{NTU}$ to $2.22 \pm 0.46$ NTU inside and increased in the filtrate to $2.85 \pm 1.74 \mathrm{NTU}$, the turbidity values of all water samples collected lies in the allowable limits of drinking water. The decreasing in turbidity in water in pottery jugs (A and B) may be attributed to the presence of clay and silt fractions which its percent reached to (4, 0 and 9, $1 \%)$, respectively, Table 2 . As silt able to adsorb the impurities and that agreed with Ajayi and Lamidi, (2015) who indicated that the pore size of the ceramic medium is sometimes small enough to trap anything bigger than a water molecule. Bielefeldt et al. (2010) mentioned that the pore sizes of ceramic water filters determine the ability to remove particles and pathogens from water. The results are in agreement with Zereffa and Bekalo (2017) who stated that the microbial removal efficiency of ceramic filters ranged from $80.00 \%$ to $97.50 \%$; they added that the microbial and turbidity removal efficiency of the ceramic filters in crease with the increase of the percentage of clay in the composition.

The mean concentration of TH in water in pottery jugs (A and C) through all sites increase from $(103.00 \pm 42.88$ and $103.00 \pm 42.88 \mathrm{mg} / \mathrm{l})$ to $(120.00 \pm 6.53$ and $142.00 \pm 10.07 \mathrm{mg} / \mathrm{l})$ inside and increase in the filtrate to $(381.10 \pm 53.36$ and $494.50 \pm 86.09 \mathrm{mg} / \mathrm{l})$, respectively. The mean concentration of $\mathrm{TH}$ in water in pottery jugs (B) decreased from $103 \pm 42.88$ $\mathrm{mg} / \mathrm{l}$ to $69.25 \pm 54.41 \mathrm{mg} / \mathrm{l}$ inside and reached to $97.0 \pm 41.58$ $\mathrm{mg} / \mathrm{l}$ in the filtrate. In addition, the mean concentration of $\mathrm{Ca}^{++}$ and $\mathrm{Mg}^{++}$hardness in water in pottery jugs ( $\mathrm{A}$ and $\mathrm{C}$ ) increase inside and in the filtrate, while the mean concentration of $\mathrm{Ca}^{++}$ and $\mathrm{Mg}^{++}$hardness in water in pottery jugs (B) decreased from $(38.10 \pm 9.09$ and $64.90 \pm 38.34 \mathrm{mg} / \mathrm{l})$ to $(20.44 \pm 19.83$ and $48.73 \pm 42.37 \mathrm{mg} / \mathrm{l})$ inside, respectively, and reached to $(34.76 \pm 10.52$ and $62.44 \pm 31.70 \mathrm{mg} / \mathrm{l})$, respectively, in the filtrate. The results in Table 3 indicated that the removal efficiency of turbidity in pottery jugs (A) and (B) was 38.3 and $31.93 \%$, respectively, inside the jugs, while the percentage of removal reached to 48.9 and $39.16 \%$, respectively, in the filtrate for the same jugs. On the other hand, the removal efficiency of $\mathrm{TH}, \mathrm{Ca}^{++}$and $\mathrm{Mg}^{++}$hardness in pottery jugs (A) were $32.7,46.35$ and $24.91 \%$, respectively, insides the jug, while reduced to 5.8, 8.76 and $3.79 \%$, respectively, in the filtrate.

On the contrary, pottery jugs (C) showed his lack of turbidity, $\mathrm{TH}$, and $\mathrm{Ca}^{++}$hardness removal were $0.0 \%$, except $\mathrm{Mg}^{++}$hardness, its percentage of removal was $14.4 \%$. The removal of cations and anions might be due to the ion exchange on the ceramic surface, the central cations in clay structure, aluminum, and silicon, with higher charge might be replaced with lower charge ions such as magnesium and calcium by leaving net negative charge (Zereffa and Bekalo, 2017). Through the results, we found that pottery jugs (B) which purchased from Kafr El-Zyate city had high performance in decreasing turbidity, $\mathrm{TH}, \mathrm{Ca}^{++}$and $\mathrm{Mg}^{++}$ 


\section{Journal of Environmental Sciences, 2018; Vol. 47, No. 3-4 : 103-113}

hardness in drinking water. This result in accordance with Brown and Sobsey (2007) who found that the filter's demonstrated effectiveness in improving water quality and health, over a wide range of conditions, makes it among the best available options for household water treatment. Also, this is in agreement with Sagara (2000) who indicated that the filter systems had very high turbidity removal efficiencies and the system reduced the turbidity level of water to less than 1 NTU. The filtration process is a simple and an effective method of treating drinking water, and thus it is a suitable process to be used in point-of-use treatment systems. The filtration process does not require any addition of chemicals and can be operated without a power supply. It is also readily adaptable to household-scale systems. In the filtration systems, the most commonly used filter medium is sand; however, media such as anthracite, crushed magnetite, garnet, coconut, husks and other natural and inert synthetic materials are also used. Medium type, size, porosity, pore size and available surface area of the medium are factors determining the effectiveness of the filtration removal process. There are systems for removing hardness, and others to remove dissolved organics by adsorption filters (Sagara, 2000).

The values of WQI and AWQI in Table 4, were calculated according to EMH (2007) and Egyptian Standards EEAA (1994). According to Table 4, the concentrations of examined physicochemical parameters in drinking tap water and inside the pottery jugs and in the filtrate were within the safe limits. The results showed that AWQI values of drinking water samples in pottery jugs (A): (Before, inside and filtrate) were $41.86,42.7$ and 62.54 , respectively, and in pottery jugs (B) were 39.9, 36.3 and 41.4, respectively. While AWQI values in pottery jugs (C) were $38.7,45.9$ and 96.8, respectively, that means that the drinking water samples in a pottery jug (A, B and C) are classified under good water quality during the sampling period. Pottery jugs (B) represented the best one in WQI and AWQI for inside and the filtrate. Also, Pottery jugs (B) improved its ability in the reduction of turbidity, $\mathrm{TH}, \mathrm{Ca}^{++}$and $\mathrm{Mg}^{++}$hardness concentrations, that may be attributed to its body composition of silt and the high quality of clay. The water inside the pottery jugs (B) had high quality than in the filtrate.

\subsection{Total Coliform MPN Analysis of Drinking Water Samples.}

The results of the MTF technique for measuring total coliform bacteria are expressed in terms of the most probable number (MPN) index/100 $\mathrm{ml}$ of microorganisms, all drinking water samples of pottery jugs, before, inside and filtrate give negative results when five tubes are used per dilution $(10 \mathrm{ml}, 1$ $\mathrm{ml}, 0.1 \mathrm{ml}$ ) and inoculated on Lauryl tryptose medium.

\subsection{Heavy Metal Analysis of Drinking Water Samples}

Results in Figure 3 indicated that the mean concentration of Fe in water in pottery jugs (B) through all sites increased from $195.5 \pm 22.1$ to $488.8 \pm 450.0 \mu \mathrm{g} / \mathrm{L}$ inside the jugs and reached to $553.5 \pm 421.6 \mu \mathrm{g} / \mathrm{L}$ in the filtrate. While the mean levels of $\mathrm{Zn}, \mathrm{Cu}, \mathrm{Mn}$ and $\mathrm{Pb}$ decreased from $(113.3 \pm 15.2$, $165.3 \pm 121.8,164.5 \pm 82.3$ and $0.53 \pm .39 \mu \mathrm{g} / \mathrm{L}$, respectively,) to $(108.3 \pm 74.3,60.0 \pm 76.9,97.3 \pm 126.2$ and $0.04 \pm 0.04 \mu \mathrm{g} / \mathrm{L}$, respectively,) inside the jugs. In contrast, the concentration of $\mathrm{Cd}$ increased from $0.07 \pm 0.03$ to $0.11 \pm 0.04$ inside the jugs. On the other hand, the mean concentration of $\mathrm{Zn}$ and $\mathrm{Cu}$ in water increased in the filtrate to $428.8 \pm 480.9$ and $219.3 \pm 142.4 \mu \mathrm{g} / \mathrm{L}$, respectively. In contrast, the mean concentration of $\mathrm{Mn}$ and $\mathrm{Pb}$ decreased in the filtrate to $94.3 \pm 73.0$ and $0.12 \pm 0.013 \mu \mathrm{g} / \mathrm{L}$, respectively.

Pottery jugs (B) improved its efficiency in decreasing concentrations of some heavy metals as $\mathrm{Zn}, \mathrm{Cu}, \mathrm{Mn}, \mathrm{Pb}$, and $\mathrm{Cd}$. Heavy metals can enter a water supply by industrial and consumer waste, or even from rain breaking down soils and releasing heavy metals into streams, lakes, rivers, and groundwater (El-Zeiny, 2010). Soils irrigated by wastewater accumulate heavy metals such as $\mathrm{Cd}, \mathrm{Zn}, \mathrm{Cr}, \mathrm{Ni}, \mathrm{Pb}$, and $\mathrm{Mn}$ in surface soil. When the capacity of the soil to retain heavy metals is reduced due to repeated use of wastewater, soil can release heavy metals into groundwater or soil solution available for plant uptake (Sharma et al. 2006). Heavy metals $(\mathrm{Zn}, \mathrm{Cd}, \mathrm{Cu} \mathrm{Mn}$ and $\mathrm{Pb}$ ) values of the drinking tap water samples were below the permissible limits of EMH (2007), and WHO (2011), except the concentration of Fe inside and in the filtrate, was above the safe limit Table 5. That may be attributed to the pollution of fired clay or contamination of water used in manufacture by a high concentration of Fe. High level of iron may be due to soil pollution, vehicular and industrial emissions and crust re-suspension. Iron is originated mainly from the soil type and construction work materials. It is also clear that auto-exhaust Fe particulates were added to the natural $\mathrm{Fe}$, which is a major constituent of earth crust (Hasballah and Beheary, 2016). Pollution index (PI) of drinking water in pottery jugs (C) showed that the degree of heavy metals contamination in water before, inside and in the filtrate is no effect $(<1)$ Table 6 .

In Table 7, the results of drinking tap water analysis in the pottery jugs (A, B and C) were analyzed by two ways ANOVA. TDS, $\mathrm{pH}$, and turbidity showed a non-significant variation among jugs $(\mathrm{P}>0.05)$, while salinity, $\mathrm{EC}, \mathrm{TH}, \mathrm{Ca}^{++}$ hardness showed highly significant variation $(\mathrm{P} \leq 0.001)$. $\mathrm{Mg}^{++}$hardness showed an intermediate significant variation among jugs $(\mathrm{P} \leq 0.01)$. Moreover, $\mathrm{pH}$, TDS, salinity, EC, TH, $\mathrm{Ca}^{++}$and $\mathrm{Mg}^{++}$hardness showed highly significant variation between filtration efficiency (before, inside and filtrate) $(\mathrm{P} \leq$ 0.001 ), except turbidity showed a non-significant variation. On the other hand, TDS, salinity, EC, TH and $\mathrm{Ca}^{++}$hardness showed highly significant variation between jugs with filtration efficiency $(\mathrm{P} \leq 0.001)$, while $\mathrm{pH}$ and turbidity showed a non-significant variation. $\mathrm{Mg}^{++}$hardness showed an intermediate significant variation between jugs with filtration efficiency $(\mathrm{P} \leq 0.01)$. In Table 8 the results of heavy metals in drinking tap water samples analysis in the different sites in pottery jug (B) were analyzed by one way ANOVA. Fe, Zn, $\mathrm{Cd}, \mathrm{Cu}, \mathrm{Mn}$, and $\mathrm{Pb}$ showed a non-significant variation $(\mathrm{P}>$ 0.05 ). These results are in accordance with El-Hamid and Hegazy (2017) who mentioned that there is no significant among heavy metals concentrations in groundwater samples assessed by one way ANOVA. 
Journal of Environmental Sciences, 2018; Vol. 47, No. 3-4 : 103-113

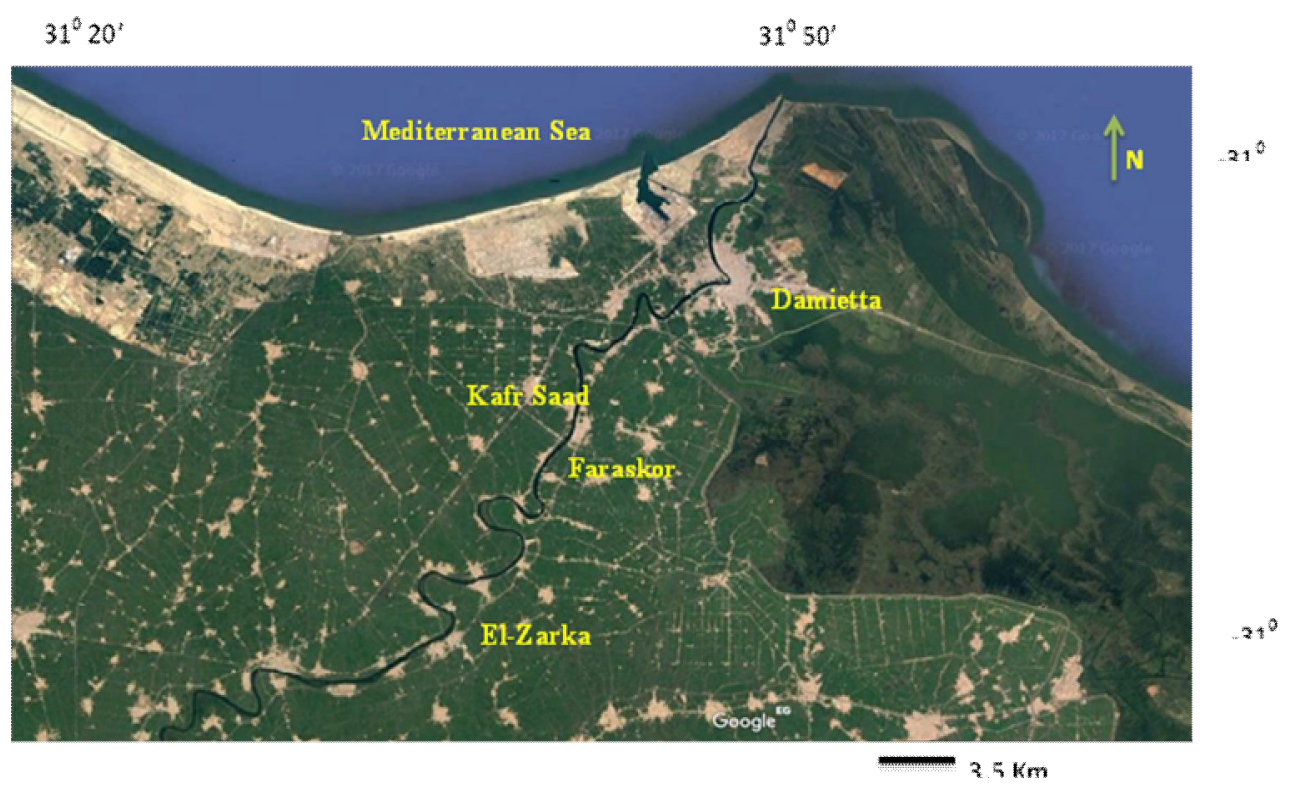

Fig. 1: Location map of the study area

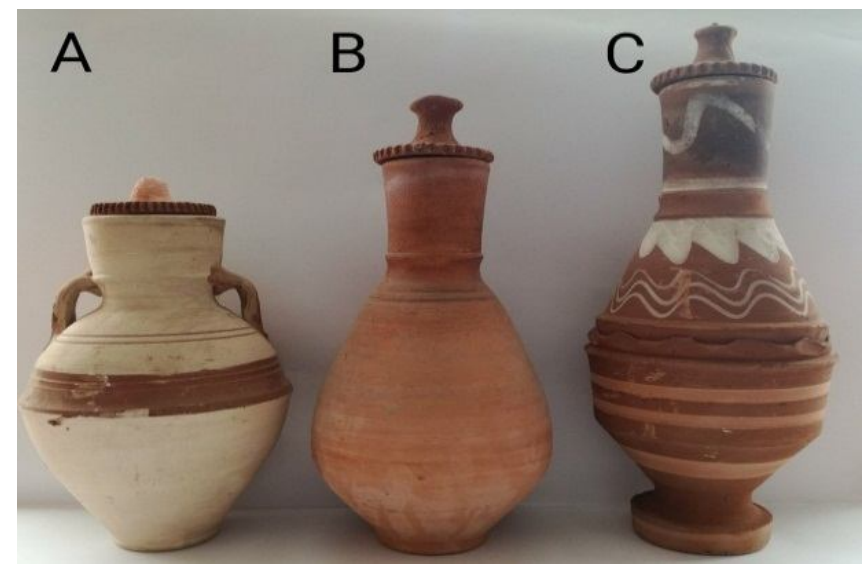

Fig. 2: Pottery jug (A), four of it purchased from Damietta Governorate; pottery jug (B) four of it purchased from El-Gharbia Governorate and Pottery jug (C), four of it purchased from El-Menya Governorate.

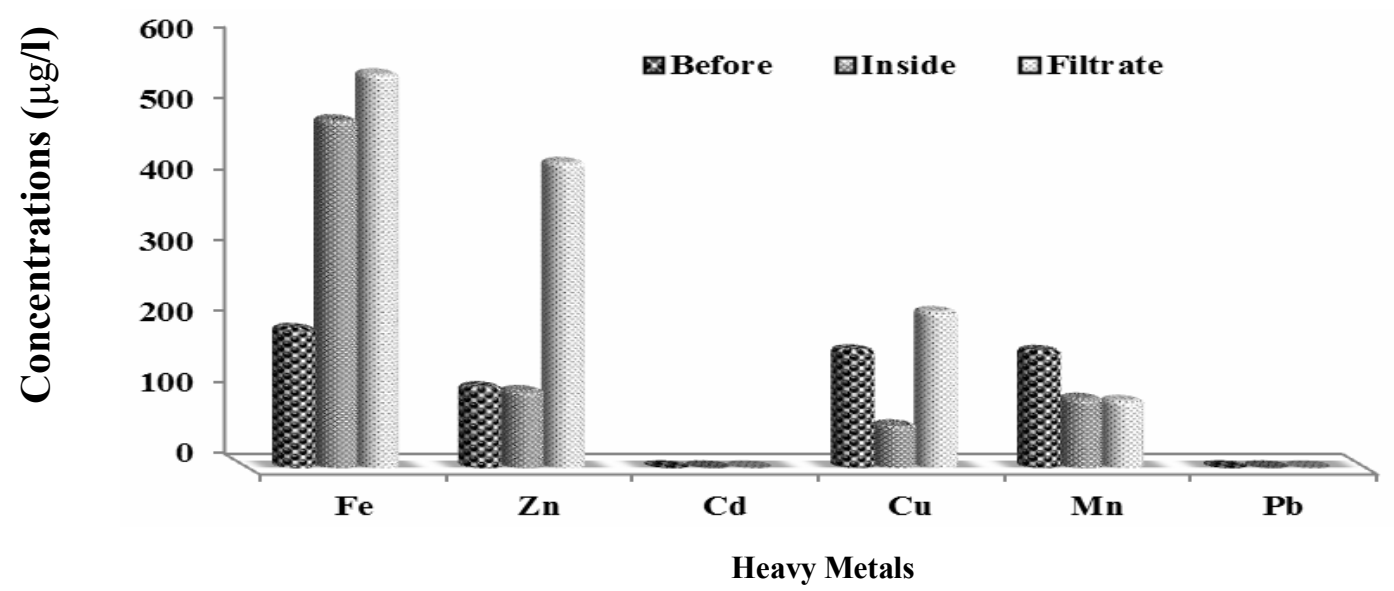

Fig. 3: Mean concentrations of heavy metals $(\mu \mathrm{g} / \mathrm{l})$ of drinking tap water through all sites in pottery jugs (B), before, inside and filtrate 


\section{Journal of Environmental Sciences, 2018; Vol. 47, No. 3-4 : 103-113}

Table 1: Mean Concentrations \pm S.D* of physico-chemical parameters of drinking tap water through all sites in pottery jugs (A, B and C) $\mathrm{SD}^{*}=$ Standard Deviation

\begin{tabular}{|c|c|c|c|c|c|c|c|c|c|}
\hline \multirow[t]{2}{*}{ Parameters } & \multicolumn{3}{|c|}{ Before } & \multicolumn{3}{|c|}{ Inside } & \multicolumn{3}{|c|}{ Filtrate } \\
\hline & (A) & (B) & (C) & (A) & (B) & (C) & (A) & (B) & (C) \\
\hline Color & Colorless & Colorless & Colorless & Colorless & Colorless & Colorless & Colorless & Colorless & $\begin{array}{l}\text { Slightly } \\
\text { colored }\end{array}$ \\
\hline Taste & Tasteless & Tasteless & Tasteless & Tasteless & Tasteless & Tasteless & Tasteless & Tasteless & Objectionable \\
\hline Odor & Odorless & Odorless & Odorless & Odorless & Odorless & Odorless & Odorless & Odorless & Odorless \\
\hline $\mathrm{pH}$ & $7.81 \pm 0.5$ & $7.35 \pm 0.2$ & $7.36 \pm 0.3$ & $8.08 \pm 0.2$ & $8.40 \pm 0.3$ & $8.25 \pm 0.3$ & $8.35 \pm 0.40$ & $8.78 \pm 0.05$ & $8.25 \pm 0.34$ \\
\hline $\begin{array}{l}\text { Turbidity } \\
\text { (NTU) }\end{array}$ & $2.35 \pm 1.4$ & $2.63 \pm 0.6$ & $1.73 \pm 0.2$ & $1.45 \pm 0.5$ & $1.79 \pm 0.7$ & $2.22 \pm 0.5$ & $1.20 \pm 0.2$ & $1.60 \pm 0.3$ & $2.85 \pm 1.7$ \\
\hline $\begin{array}{c}\text { TDS } \\
(\mathrm{mg} / \mathrm{L})\end{array}$ & $226.75 \pm 14.1$ & $192.25 \pm 5.0$ & $217.10 \pm 24.2$ & $256.50 \pm 11.0$ & $201.75 \pm 5.5$ & $228.0 \pm 22.3$ & $375.50 \pm 48.5$ & $246 \pm 9.4$ & $571 \pm 83.6$ \\
\hline $\begin{array}{c}\text { E.C } \\
(\mu \mathrm{s} / \mathrm{cm})\end{array}$ & $502 \pm 147.2$ & $336.25 \pm 75.0$ & $443.25 \pm 61.0$ & $508.50 \pm 19.1$ & $406.75 \pm 13.5$ & $491.0 \pm 54.7$ & $776.0 \pm 115.1$ & $505.25 \pm 21.1$ & $1022 \pm 142$ \\
\hline Salinity (\%) & $0.20 \pm 0$ & $0.20 \pm 0$ & $0.20 \pm 0.0$ & $0.23 \pm 0.0$ & $0.20 \pm 0$ & $0.23 \pm 0.0$ & $0.35 \pm 0.1$ & $0.23 \pm 0.1$ & $0.60 \pm 0.1$ \\
\hline $\begin{array}{c}\text { Total Hardnes } \\
(\mathrm{mg} / \mathrm{L})\end{array}$ & $103.00 \pm 42.9$ & $103 \pm 42.9$ & $103.00 \pm 42.9$ & $120.00 \pm 6.5$ & $69.25 \pm 54.4$ & $142.00 \pm 10.1$ & $381.10 \pm 53.4$ & $97.0 \pm 41.6$ & $494.50 \pm 86.1$ \\
\hline $\begin{array}{c}\mathrm{Ca}^{++} \text {Hardness } \\
(\mathrm{mg} / \mathrm{L})\end{array}$ & $38.10 \pm 9.1$ & $38.10 \pm 9.1$ & $38.10 \pm 9.1$ & $40.08 \pm 5.1$ & $20.44 \pm 19.8$ & $86.50 \pm 36.4$ & $76.25 \pm 28.1$ & $34.76 \pm 10.5$ & $395.00 \pm 111.6$ \\
\hline $\begin{array}{c}\mathrm{Mg}^{++} \text {Hardness } \\
(\mathrm{mg} / \mathrm{L})\end{array}$ & $64.90 \pm 38.3$ & $64.90 \pm 38.3$ & $64.90 \pm 38.3$ & $79.93 \pm 6.6$ & $48.73 \pm 42.4$ & $55.50 \pm 35.8$ & $304.86 \pm 73.8$ & $62.44 \pm 31.7$ & $99.50 \pm 136.5$ \\
\hline $\begin{array}{c}\text { Total Coliform } \\
\text { (MPN } \\
\text { Index/100ml) }\end{array}$ & Negative & Negative & Negative & Negative & Negative & Negative & Negative & Negative & Negative \\
\hline
\end{tabular}

Table 2: Composition of the pottery jugs body in percentage (\%).

\begin{tabular}{cccc}
\hline Composition (\%) & Pottery jugs (A) & Pottery jugs (B) & Pottery jugs (C) \\
\hline Sand & 96 & 90 & 90 \\
\hline Clay & 4 & 9 & 10 \\
\hline Silt & 0 & 1 & 0 \\
\hline
\end{tabular}

Table 3: Removal efficiency (\%) of pottery jugs (A, B and C)

\begin{tabular}{ccccccccc}
\hline \multirow{2}{*}{ Jugs } & \multicolumn{2}{c}{ Turbidity } & \multicolumn{2}{c}{ Total hardness } & $\mathrm{Ca}^{++}$ & Hardness & \multicolumn{2}{c}{$\mathrm{Mg}^{++}$Hardness } \\
\cline { 2 - 9 } & Inside & Filtrate & Inside & filtrate & Inside & Filtrate & Inside & Filtrate \\
\hline A & 38.3 & 48.9 & 0.0 & 0.0 & 0.0 & 0.0 & 0.0 & 0.0 \\
\hline B & 31.93 & 39.16 & 32.7 & 5.8 & 46.35 & 8.76 & 24.91 & 3.79 \\
\hline C & 0.0 & 0.0 & 0.0 & 0.0 & 0.0 & 0.0 & 14.4 & 0.0 \\
\hline
\end{tabular}

Table 4: WQI and AWQI of drinking tap water in Pottery jugs (A).

\begin{tabular}{|c|c|c|c|c|c|c|c|}
\hline \multirow{3}{*}{ Parameters } & \multirow{3}{*}{$\mathbf{S i}$} & \multicolumn{6}{|c|}{ Pottery jugs (A) } \\
\hline & & \multicolumn{3}{|c|}{$\mathbf{V i}$} & \multirow{2}{*}{ 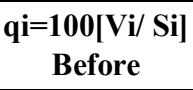 } & \multirow{2}{*}{$\begin{array}{c}q i=100[V i / S i] \\
\text { Inside }\end{array}$} & \multirow{2}{*}{$\begin{array}{c}q i=100[\mathrm{Vi} / \mathrm{Si}] \\
\text { Filtrate }\end{array}$} \\
\hline & & Before & Inside & Filtrate & & & \\
\hline $\mathrm{pH}$ & $6.5-9.5$ & 7.81 & 8.08 & 8.35 & 97.6 & 101 & 104.4 \\
\hline Turbidity (NTU) & 5 & 2.35 & 1.45 & 1.20 & 47 & 29 & 24 \\
\hline TDS (mg/L) & 500 & 226.75 & 256.50 & 375.5 & 45.4 & 51.3 & 75.1 \\
\hline $\mathrm{EC}(\mu \mathrm{s} / \mathrm{cm})$ & 2500 & 502.0 & 508.5 & 776 & 20.1 & 20.3 & 31.04 \\
\hline $\mathrm{TH}(\mathrm{mg} / \mathrm{L})$ & 500 & 103.0 & 120.0 & 381.1 & 20.6 & 24 & 76.2 \\
\hline $\left.\mathrm{Ca}^{++(} \mathrm{mg} / \mathrm{L}\right)$ & 200 & 38.10 & 40.08 & 76.25 & 19.05 & 20.04 & 38.1 \\
\hline $\mathrm{Mg}^{++(\mathrm{mg} / \mathrm{L})}$ & 150 & 64.90 & 79.93 & 304.86 & 43.3 & 53.3 & 203.24 \\
\hline $\mathrm{WQI}=\sum q \mathrm{i}=1$ & - & - & - & - & 293.05 & 298.94 & 437.84 \\
\hline $\mathrm{AWQI}=\sum \mathrm{qi} / \mathrm{n}$ & - & - & - & - & 41.86 & 42.7 & 62.54 \\
\hline
\end{tabular}

TDS: Total dissolved solids, EC: Electrical conductivity, TH: Total hardness, WQI: Water quality index, AWQI: Average water quality index 
Journal of Environmental Sciences, 2018; Vol. 47, No. 3-4 : 103-113

Table 4: Continued, WQI and AWQI of the drinking water in Pottery jugs (B).

\begin{tabular}{|c|c|c|c|c|c|c|c|}
\hline \multirow{3}{*}{ Parameters } & \multirow{3}{*}{$\mathbf{S i}$} & \multicolumn{6}{|c|}{ Pottery jugs (B) } \\
\hline & & \multicolumn{3}{|c|}{$\mathbf{V i}$} & \multirow{2}{*}{ 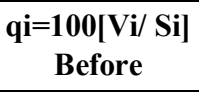 } & \multirow{2}{*}{$\begin{array}{c}q i=100[V i / S i] \\
\text { Inside }\end{array}$} & \multirow{2}{*}{$\begin{array}{c}q i=100[\mathrm{Vi} / \mathrm{Si}] \\
\text { Filtrate }\end{array}$} \\
\hline & & Before & Inside & Filtrate & & & \\
\hline $\mathrm{pH}$ & $6.5-9.5$ & 7.35 & 8.40 & 8.78 & 91.9 & 105 & 109.8 \\
\hline Turbidity (NTU) & 5 & 2.63 & 1.79 & 1.60 & 52.6 & 35.8 & 32 \\
\hline TDS (mg/L) & 500 & 192.25 & 201.75 & 246 & 38.45 & 40.35 & 49.2 \\
\hline $\mathrm{EC}(\mu \mathrm{s} / \mathrm{cm})$ & 2500 & 336.25 & 406.75 & 505.25 & 13.45 & 16.27 & 20.21 \\
\hline $\mathrm{TH}(\mathrm{mg} / \mathrm{L})$ & 500 & 103.42 & 69.25 & 97.0 & 20.7 & 13.9 & 19.4 \\
\hline $\mathrm{Ca}++(\mathrm{mg} / \mathrm{L})$ & 200 & 38.10 & 20.44 & 34.76 & 19.05 & 10.22 & 17.4 \\
\hline $\mathrm{Mg}++(\mathrm{mg} / \mathrm{L})$ & 150 & 64.90 & 48.73 & 62.44 & 43.3 & 32.5 & 41.6 \\
\hline $\mathrm{WQI}=\sum \mathrm{qi} i=1$ & - & - & - & - & 279.45 & 254.04 & 289.61 \\
\hline $\mathrm{AWQI}=\sum \mathrm{qi} / \mathrm{n}$ & - & - & - & - & 39.9 & 36.3 & 41.4 \\
\hline
\end{tabular}

Table (4): Continued, WQI and AWQI of the drinking water in Pottery jugs (C).

\begin{tabular}{|c|c|c|c|c|c|c|c|}
\hline \multirow{3}{*}{ Parameters } & \multirow{3}{*}{$\mathbf{S i}$} & \multicolumn{6}{|c|}{ Pottery jugs (C) } \\
\hline & & \multicolumn{3}{|c|}{$\mathbf{V i}$} & \multirow{2}{*}{$\begin{array}{c}q i=100[\mathrm{Vi} / \mathrm{Si}] \\
\text { Before }\end{array}$} & \multirow{2}{*}{$\begin{array}{c}q \mathbf{i}=\mathbf{1 0 0}[\mathrm{Vi} / \mathrm{Si}] \\
\text { Inside }\end{array}$} & \multirow{2}{*}{$\begin{array}{c}q i=100[\mathrm{Vi} / \mathrm{Si} \\
\text { Filtrate }\end{array}$} \\
\hline & & Before & Inside & Filtrate & & & \\
\hline $\mathrm{pH}$ & $6.5-9.5$ & 7.36 & 8.25 & 8.25 & 91.9 & 103.1 & 103.1 \\
\hline Turbidity (NTU) & 5 & 1.73 & 2.22 & 2.85 & 34.6 & 44.4 & 57.0 \\
\hline TDS (mg/L) & 500 & 217.10 & 228.0 & 571.0 & 43.42 & 45.6 & 114 \\
\hline $\mathrm{EC}(\mu \mathrm{s} / \mathrm{cm})$ & 2500 & 443.25 & 491.0 & 1022.0 & 17.73 & 19.64 & 40.9 \\
\hline $\mathrm{TH}(\mathrm{mg} / \mathrm{L})$ & 500 & 103.0 & 142.0 & 494.50 & 20.6 & 28.4 & 98.9 \\
\hline $\mathrm{Ca}++(\mathrm{mg} / \mathrm{L})$ & 200 & 38.10 & 86.50 & 395.0 & 19.02 & 43.25 & 197.5 \\
\hline $\mathrm{Mg}++(\mathrm{mg} / \mathrm{L})$ & 150 & 64.90 & 55.50 & 99.50 & 43.3 & 37 & 66.3 \\
\hline $\mathrm{WQI}=\sum \mathrm{q}_{\mathrm{i}} \mathrm{i}=1$ & - & - & - & - & 270.57 & 321.39 & 677.7 \\
\hline $\mathrm{AWQI}=\sum \mathrm{q}_{\mathrm{i}} / \mathrm{n}$ & - & - & - & - & 38.7 & 45.9 & 96.8 \\
\hline
\end{tabular}

Table 5: Permissible limits for heavy metals of drinking water

\begin{tabular}{ccccccc}
\hline & \multicolumn{4}{c}{ Metals (mg/l) } \\
\cline { 2 - 7 } & $\mathbf{C d}$ & $\mathbf{C u}$ & $\mathbf{M n}$ & $\mathbf{P b}$ & $\mathbf{F e}$ & $\mathbf{Z n}$ \\
\hline Permissible limit of WHO (2011) & 0.003 & 2.0 & 0.4 & 0.01 & 0.3 & 3.0 \\
\hline Permissible limit of EMH (2007) & 0.003 & 2.0 & 0.4 & 0.01 & 0.3 & 3.0 \\
\hline
\end{tabular}

Table 6: Heavy metal pollution index (PI) of the drinking water in Pottery jugs (B).

\begin{tabular}{cccccccc}
\hline Metal & Ci (before) & Ci (inside) & Ci (Filtrate) & Si & $\begin{array}{c}\text { (Ci/Si)/Nm } \\
\text { Before }\end{array}$ & $\begin{array}{c}(\mathbf{C i} / \mathbf{S i}) / \mathbf{N m} \\
\text { inside }\end{array}$ & $\begin{array}{c}(\mathbf{C i} / \mathbf{S i}) / \mathbf{N m} \\
\text { filtrate }\end{array}$ \\
\hline $\mathrm{Fe}$ & 0.20 & 0.49 & 0.80 & 0.3 & 0.042 & 0.272 & 0.443 \\
\hline $\mathrm{Zn}$ & 0.11 & 0.11 & 0.43 & 3.0 & 0.009 & 0.009 & 0.024 \\
\hline $\mathrm{Cd}$ & 0.00007 & 0.0001 & 0.00007 & 0.003 & 0.004 & 0.006 & 0.004 \\
\hline $\mathrm{Cu}$ & 0.17 & 0.06 & 0.22 & 2.0 & 0.014 & 0.005 & 0.018 \\
\hline $\mathrm{Mn}$ & 0.16 & 0.10 & 0.09 & 0.4 & 0.07 & 0.042 & 0.04 \\
\hline $\mathrm{Pb}$ & 0.00053 & 0.00004 & 0.00012 & 0.01 & 0.009 & 0.0007 & 0.002 \\
\hline$P I=\sum_{i=1}^{\mathrm{n}}\left(\frac{C_{i}}{S_{i}}\right) / \mathrm{Nm}$ & & & & & 0.148 & 0.335 & 0.531 \\
\hline
\end{tabular}


Table 7: Two-way analysis of variance (ANOVA) of physico-chemical parameters of drinking tap water samples through all jugs (A, B and C).

Non-significant $(\mathrm{P}>0.05), *=$ low significant $(\mathrm{P} \leq 0.05)$,

$* *=$ intermediate significant $(\mathrm{P} \leq 0.01)$ and $* * *=$ highly significant $(\mathrm{P} \leq 0.001)$.

\begin{tabular}{|c|c|c|c|}
\hline Parameters & Source & $\mathrm{F}$ & $\mathrm{P}$ \\
\hline \multirow{3}{*}{$\mathrm{pH}$} & Jugs & 1.299 & $0.290^{\circ o}$ \\
\hline & Filtration efficiency & 24.565 & $0.000 * * *$ \\
\hline & Jugs* Filtration efficiency & 2.208 & $0.096^{\circ o}$ \\
\hline \multirow{3}{*}{ TDS } & Jugs & 1.157 & $0.359^{\circ o}$ \\
\hline & Filtration efficiency & 34.733 & $0.000 * * *$ \\
\hline & Jugs* Filtration efficiency & 5.318 & $0.003 * *$ \\
\hline \multirow{3}{*}{ Salinity } & Jugs & 18.233 & $0.000 * * *$ \\
\hline & Filtration efficiency & 47.100 & $0.000 * * *$ \\
\hline & Jugs* Filtration efficiency & 15.009 & $0.000 * * *$ \\
\hline \multirow{3}{*}{$\mathrm{EC}$} & Jugs & 96.753 & $0.000 * * *$ \\
\hline & Filtration efficiency & 67.529 & $0.000 * * *$ \\
\hline & Jugs* Filtration efficiency & 17.992 & $0.000 * * *$ \\
\hline \multirow{3}{*}{ Turbidity } & Jugs & 1.499 & $0.242^{\circ \mathrm{oo}}$ \\
\hline & Filtration efficiency & 0.854 & $0.437^{\text {oo }}$ \\
\hline & Jugs* Filtration efficiency & 2.284 & $0.087^{\text {oo }}$ \\
\hline \multirow{3}{*}{$\mathrm{TH}$} & Jugs & 31.653 & $0.000 * * *$ \\
\hline & Filtration efficiency & 76.283 & $0.000 * * *$ \\
\hline & Jugs* Filtration efficiency & 18.200 & $0.000 * * *$ \\
\hline \multirow{3}{*}{$\mathrm{Ca}^{++}$Hardness } & Jugs & 39.059 & $0.000 * * *$ \\
\hline & Filtration efficiency & 33.188 & $0.000 * * *$ \\
\hline & Jugs* Filtration efficiency & 24.178 & $0.000 * * *$ \\
\hline \multirow{3}{*}{$\begin{array}{c}\mathrm{Mg}^{++} \\
\text {Hardness }\end{array}$} & Jugs & 7.525 & $0.003 * *$ \\
\hline & Filtration efficiency & 8.558 & $0.001 * * *$ \\
\hline & Jugs* Filtration efficiency & 5.175 & $0.003 * *$ \\
\hline
\end{tabular}

Table 8: One-way analysis of variance (ANOVA) of Heavy metals of water samples in pottery jugs (B).

Non-significant $(\mathrm{P}>0.05), *=$ low significant $(\mathrm{P} \leq 0.05)$,

\begin{tabular}{c|c|c}
$* * *$ intermediate significant $(\mathrm{P} \leq 0.01)$ and $* * *=$ highly significant $(\mathrm{P} \leq 0.001)$. \\
\hline Parameter & F. test & Significant \\
\hline $\mathrm{Fe}$ & 1.274 & $0.326^{\circ \circ}$ \\
\hline $\mathrm{Zn}$ & 1.718 & $0.233^{\circ \circ}$ \\
\hline $\mathrm{Cd}$ & 2.171 & $0.170^{\circ \circ}$ \\
\hline $\mathrm{Cu}$ & 1.919 & $0.202^{\circ \circ}$ \\
\hline $\mathrm{Mn}$ & 0.675 & $0.533^{\circ 0}$ \\
\hline $\mathrm{Pb}$ & 1.008 & $0.403^{\circ \circ}$ \\
\hline
\end{tabular}




\section{Conclusion}

Pottery jugs (B) represented the best one in WQI and AWQI for inside and for the filtrate of drinking tap water and improved its efficiency in decreasing concentrations of some heavy metals in water as $\mathrm{Zn}, \mathrm{Cu}, \mathrm{Mn}, \mathrm{Pb}$ and $\mathrm{cd}$ inside the jugs. That may be attributed to its composition of silt and the high quality of clay. Pottery jugs as a filter are recommended for use in water treatment at the household level. Further efforts are needed to define and implement appropriate manufacturing procedures and product performance characteristics of these filters in order to achieve products of acceptable quality, that are capable of adequate turbidity and some of heavy metals reductions from water, by adapting the local production of clay and other ceramic ware now used for other purposes to water treatment.

Acknowledgment: The author would like to thank the staff members and colleagues of the Environmental Sciences Department, Faculty of Science, Damietta University, for their continuous cooperation and encouragement.

\section{References}

Ajayi, B. A., and Lamidi, Y. D. (2015). Formulation of Ceramic Water Filter Composition for the Treatment of Heavy Metals and Correction of Physiochemical Parameters in Household Water. Art and Design Review, 3: 94-100.

Al-Asmar, A. M. (2006). Impact assessment of some industrial activates in the surrounding environment, Damietta, Egypt. Ph.D. Thesis, Environmental Sciences Department, Damietta Faculty of Science, Mansoura University, Egypt: 126-128.

American Public Health Association (APHA) (1992). Standard Methods for the Examination of Water and Wastewater, Washington, 18th ed. DC.

Badr, E.; ElSonbati, M. and Nassef, M. H. (2013). Water Quality Assessment in the Nile River, Damietta Branch, Egypt. CATRINA, 8(1): 41-50.

Baker, M. N. (1948). The Quest for Pure Water: The History of Water Purification from the Earliest Records to the Twentieth Century, American Water Works Association, Denver.

Bielefeldt, A. R.; Kowalski, K.; Schilling, C.; Schreier, S., Kohler, A. and Scott Summers, R. (2010). Removal of virus to protozoan sized particles in point of-use ceramic water filters. Water Research, 44(5): 14821488.

Brown, J. and Sobsey, M. (2007). Improving Household Drinking Water Quality: Use of Ceramic Water Filters in Cambodia. The Water and Sanitation Program:3-44.

Brown, J.; Sobsey, M. and Proum, S. (2007). WSP Field Notes, Improving Household Drinking Water Quality: Use of Ceramic Water Filters in Cambodia. Cambodia : WSP, UNICEF: $1-44$.

Caerio, S.; Costa, M. H., Ramos, T. B.; Fernandes, F.; ilveira, N.; Coimbra, A. and Painho, M. (2005). Assessing heavy metal contamination in Sado Estuary sediment: An index analysis approach. Ecological Indicators, 5: $155-169$.

Egyptian Ministry of Health (EMH) (2007). Standards and specifications of water quality for drinking and domestic uses. Internal Report: 1-8.

El-Hamid, T. H., and Hegazy, A. T. (2017). Evaluation of Water Quality Pollution Indices for Groundwater Resources of New Damietta, Egypte. Ecology and Environmental Science 2(6):1-5.

El-Zeiny, M. A. (2010). Monitoring and evaluation of some pollutants at New Damietta, Damietta, Egypt. M.Sc. Thesis. Damietta. Faculty of Sciences. Mansoura University: 167.

Emoyan, O.O.; Ogban, F. E. and Akarah, E. (2005). Evaluation of Heavy metals loading of River Ijana. Nigeria. Journal of Applied Sciences and Environmental Management10(2): 121.

Gupta, D. P., Sunita and J. P. Saharan,(2009). Physiochemical Analysis of Ground Water of Selected Area of Kaithal City Haryana. India, Researcher, 1(2): 1-5.

Hasballah, F. A., and Beheary, B. S. (2016). Detection of Heavy Metals in Breast Milk and Drinking Water in Damietta Governorate, Egypt. Asian Journal of Biology, 1(2): 1-7.

Hunter, P. R. (2009). Household water treatment in developing countries: comparing different intervention types using meta-regression. Environmental Science and Technology, 43: 8991-8997.

Jaffar, M., M. Ahmad, et al. (1990). Development and Fabrication of a Ceramic Filter for Natural Water Filtration. Pakistan Journal of Scientific and Industrial Research 33 (5-6): 243-246.

LeChevallier, M. W., and K. K., Au (2000). Impact of Treatment on Microbial Water Quality: A Review Document on Treatment Efficiency to Remove Pathogens, (Draft).World Health Organization, Geneva.

Lee, J. S.; Chon, H.T.; Kim, J. S.; Kim, K.W. and Moon, H.S. (1998). Enrichment of potentially toxic elements in areas underlain by black shales and slates in Korea. Environmental Geochemistry and Health. $1^{\text {th }} 20$ (30):135-147.

Logsdon, G. S. (1990). Microbiology and Drinking Water Filtration. In: Drinking Water Microbiology: Progress and Recent Developments". G. A. McFeters (ed.). New York, Springer-Verlag: 120-146.

Odukoya, A. M., and Abimbola, A. F. (2010). Contamination assessment of surface and groundwater within and around two dumpsites. International Journal of Environmental Science and Technology.7(2): 367.

Patil, P.N; Sawant, D.V and Deshmukh, R.N. (2012). Physico-chemical parameters for testing of water-A review. International Journal of Environmental Sciences, 3(3): 1194-1207. 
Piper, C. S. (1947). Soil and plant analysis. Inter. Sci. pub. Intc. New York: 416.

Sagara, J. (2000). Study of Filtration for Point T-of-USE Drinking Water Treatment NEPAL". M.D. Thesis. NEPAL, Civil and Environmental Engineering.2013: 1-311.

Sharma, K. R.; Agrawal, M. and Marshall, F. (2006). Heavy metal contamination of soil and vegetables in suburban areas of Varanasi, India. Ecotoxicology and Environmental Safety, 66 (2): 258-266.

Sobsey, M. D.; Stauber, C. E.; Casanova, L. M.; Brown, J. M., and Elliott, M. A. (2008). Point of use household drinking water filtration: a practical, effective solution for providing sustained access to safe drinking water in the developing world, Environmental Science and Technology, 42: 4261-4267.
Tiwari, T. N., and Manzoor, A. (1988): Water Quality Index for Indian Rivers. In: Ecology and Pollution of Indian River. Ashish Publishing House, New Delhi : 271286.

United States Environmental Protection Agency (U.S. EPA) (2009). 816-F-09-004.

Van der Laan, H.; van Halem, D.; Smeets, P.; Soppe, A.; Kroesbergen, J.; Wubbels, G. and Heijman, S. (2014). Bacteria and virus removal effectiveness of ceramic pot filters with different silver applications in a longterm experiment. Water Research, 51: 47-54.

World Health Organization (WHO) (2011). Guidelines for drinking water quality, $4^{\text {th }}$ edn. Geneva.

Zereffa, A. E., and Bekalo, B. t. (2017). Clay Ceramic Filter for Water Treatment. Materials Science and Applied Chemistry, 34: 69-74. 


\section{الالنمس العربجي \\ امكاتية استخدام الاواني الفخارية كمرشحات لمياة الشرب \\ أمانى فر بي هسب الله \\ قسم العلوم البيئية_ كلية العلوم- جامعة دمياطــ دمياطـ مصر.}

تهدف هذه الدراسة الى امكانية استخدام الاو انى الفخارية ذات المساميه (الطين المحروق) فى تنقية مياه الثرب وتقليل

نسبة المعادن الثقبلة وبعض الملوثات الاخرى التى قد تتبقى بعد عملية المعالجة. تم اختبار ب ب عينه من مياه الثرب ( ماء

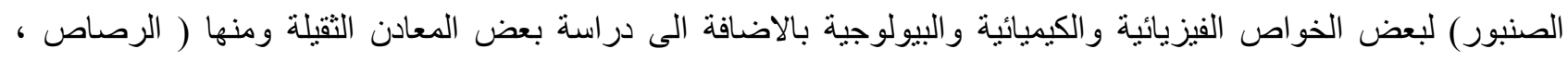
الخارصين ،المنجنيز ، و الحديد ،الكادميوم والنحاس). وقد تم اختبار هذه الخواص فى الماء قبل وضعه داخل الاناء الفخارى وداخل الاناء و ايضا فى الرشيح الخارج من الاناء خلال ؟Y ساعه. وقد تبين من الدراسة ان مثل هذه الاو انى الفخارية لها القدره

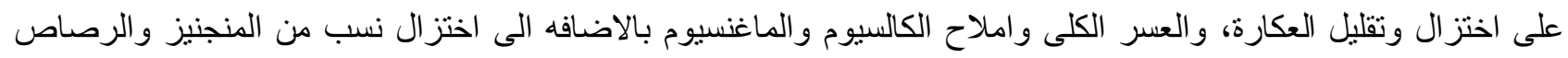

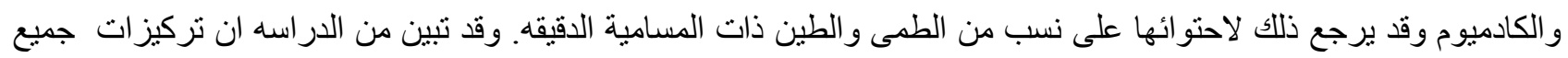
العناصر المقاسة فى الحدود المسوح بها فيما عدا تركيز عنصر الحديد داخل وخارج الاناء. 


\title{
Journal of Environmental Sciences
}

\section{JOESE 5}

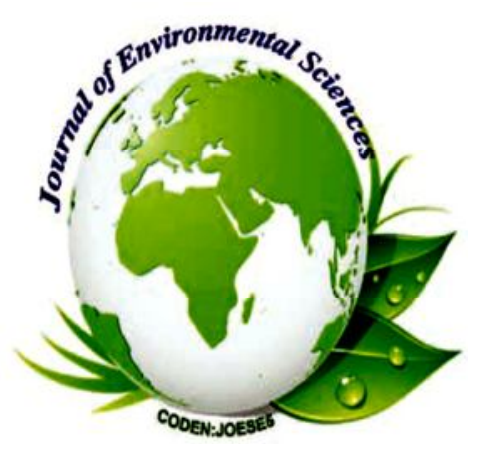

\section{The Potential Use of Pottery Jugs as Drinking Water Filters}

\author{
Amany F. Hasballah
}

Environmental Sciences Department, Faculty of Sciences, Damietta University, Damietta, Egypt.

\section{Reprint}

Volume 74, Number 3-4 : 103-113

(2018) 